\title{
An Ordoliberal Interpretation of Adam Smith
}

\author{
Content
}

I. Introduction 1

II. Smith's and Eucken's "Program of Liberty" .................................................... 4

1. Eucken and the Freiburg School of Economics on Liberty............................ 4

2. Smith's System of Natural Liberty............................................................ 5

III. Smith's and Eucken's Concept of the State ................................................ 9

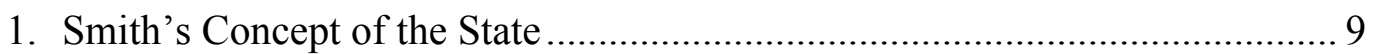

2. Exclusive Privileges, Special Interests and the Necessity of Ordnungspolitik12

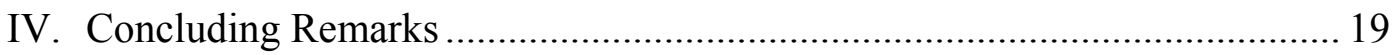

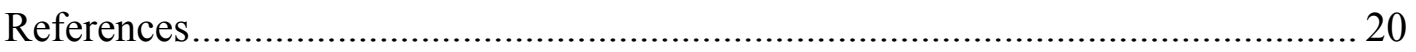

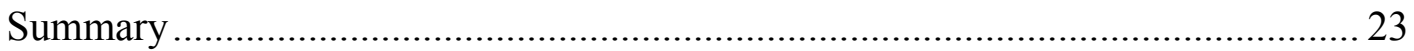

\section{Introduction}

Walter Eucken (1891-1950), main representative of German Ordoliberalism and one of the pioneers of Social Market Economy, has an ambivalent relationship to Adam Smith (1723-1790). Some might say that this relationship is at least partially negative although the parallels, which will be explored in this paper, are conspicuous. Furthermore, the imbalance or mismatch in Eucken's estimation of Smith and Kant (17241804) is obvious: On the one hand, Eucken praises Kant's concept of liberty and autonomy, and his Categorical Imperative (Eucken 1948a; 1949; 1952/2004: 176/360) ${ }^{1}$; on the other hand, he condemns Smith as a libertarian proponent of laissez faire - even though several analogies between Smith and Kant do exist. ${ }^{2}$ Kant himself pays tribute to Smith and his Theory of Moral Sentiments (TMS) (Eckstein 2004:XXXIII; Krause 1997:4/pp. 13; Kühn 2003: pp. 237). One alleged reason for this mismatch and for

1 Some authors even claim that Eucken is a Kantian (Foucault 2006; Schumann/Nutzinger 2009); cp. Wörsdörfer 2010.

2 To name just a few: the concept of an impartial spectator; favouritism of liberal republicanism; pursuing the aim of overcoming immaturity and tutelage via the public use of reason, freedom of the pen and education policy; value of economic activity for developing one's capacity for freedom (i.e. participation in the marketplace serves as a mean to enlightenment); markets not merely produce wealth, they also cultivate freedom; (restricted/framed) competition encourages virtues of mutual accommodation and responsiveness; envision of an economic world where everyone earns their place by talent, industry/hard work, effort, and merit (i.e. Leistungsgerechtigkeit/meritocracy); fighting inequality of power, monopolies and one-sided dependencies (cp. Kant 1977b; Oncken 1877; Fleischacker 1996). 
Eucken's one-sided and biased interpretation of Smith's account could be the uncritical and non-reflected adoption of the picture presented by the German Historical School. ${ }^{3}$ Another reason could be Hayek's portrayal of Smith as a representative of a spontaneous and evolutionary order (Eucken 1952/2004:53). However, these are mere speculations; it is not the aim of the following paper to pursue these conjectures. The focus is rather on the (unconscious) parallels between Eucken and Smith.

Eucken's Smith-reception starts with the Kapitaltheoretische Untersuchungen, in which Smith plays only a minor role. Eucken ascribes Smith's view as one which rests upon the divine and natural order (p. 14). In Grundlagen der Nationalökonomie (Foundations of Economics) - and this is remarkable, because it is exceptional ${ }^{4}$-, Eucken defends Smith against accusations forwarded by the Historical School, namely that Smith is rather a theorist and that he neglects history (24). Additionally, Eucken positively refers to Smith's analysis of rent-seeking groups and their ideologies influencing the mercantile economic policy (245). Astonishing is the fact, that Eucken cites exclusively the Wealth of Nations (WN), while blinding out the TMS. The only exception is a part in Eucken's Grundsätze der Wirtschaftspolitik, where Smith is delineated as among the fathers of the doctrine of the invisible hand (i.e. unintended consequences of intentional actions), and thus, as the originator of laissez faire and Paleoliberalism ${ }^{5}$ (pp. 28/pp. 351; on pp. 356, Eucken cites the invisible hand passage of TMS). Smith's natural order is again pictured as a divine, spontaneous and evolutionary one (53/195), disregarding the necessity of Wirtschaftsordnungspolitik: an ordoliberal competition policy institutionally framing market processes. Smith is almost always cited when Eucken criticises libertarianism. His main arguments against laissez faire are: the missing consideration of societal power structures and the inherent tendency towards monopolies and cartels. The self-governing invisible hand is - according to Eucken - not able to obtain the compatibility of individual interests and public welfare. ${ }^{6}$ This can only be

3 Cp. List 1842/1950:267; Hildebrand 1848/1922: pp. 21; Knies 1883/1964:225-243 accusing Smith for his alleged materialism, atomism/individualism, and egoism; cp. Schefold 2003; 2004; Eckstein 2004:LIV; Broyer 2006. See Streissler 1973:1409: “... Fälschung der Geistesgeschichte des Liberalismus durch Walter Eucken, oder seiner Vorgänger in der deutschen historischen Schule [...]. Eucken zitiert die Klassiker wenig, Smith etwa in den „Grundlagen“ nur für Unwesentlichkeiten, in den „Grundsätzen“ mit drei Standardzitaten ..."

4 In Deutschland vor und nach der Währungsreform (Eucken 1950/1996), Eucken praises $18^{\text {th }}$ century liberalism contrary to $19^{\text {th }}$ century (Paleo-)liberalism, which is criticised by Eucken (pp. 358), and he refers to the "great economic thinkers of the $18^{\text {th }}$ century" $(350)$ - without explicitly mentioning Adam Smith. Smith's Wealth of Nations is cited twice - however in a different context (i.e. free trade and economic globalisation as a peacemaking tool) (pp. 350).

5 The term ,Paleoliberalism' respectively the differentiation between Paleo- and Neoliberalism was coined by Alexander Rüstow: cp. Rüstow 1961.

6 "Die ,unsichtbare Hand“ schafft nicht ohne weiteres Formen, in denen Einzelinteresse und Gesamtinteresse aufeinander abgestimmt werden. [...] Es wird zur großen Aufgabe der Wirtschaftspolitik, die Kräfte, die aus dem Einzelinteresse entstehen, in solche Bahnen zu lenken, daß hierdurch das Gesamtinteresse gefördert wird, daß also eine sinnvolle Koordination der Einzelinteressen stattfindet." By the way, this is exactly the purpose of Smith, as the following chapters show. Eucken goes on to quote Kant in order to back his argument: „Nach [Kants] Auffassung ist es die Aufgabe des Staates, eine Form zu finden, in der ein [...] Zusammenleben und zugleich ein größtmöglicher Spielraum für die freie Entfaltung der individuellen Kräfte möglich ist. Die absolute Freiheit des Naturzustandes soll durch Gesetze eingeschränkt werden, durch die der einzelne gegen die Willkür anderer geschützt wird. Aber andererseits soll doch die freie Betätigung der vielen einzelnen im Wettbewerb mit- 
achieved via Eucken's Wettbewerbsordnung. The symptomatic title of the paragraph in which Eucken discusses Smith's theory is "Criticism of the Policy of Laissez faire". Laissez faire and libertarianism, as well as totalitarian collectivism and centrally planned economies, are the economic systems which Eucken abhors. It is one of his primary objects to draw the line between Ordoliberalism, laissez faire and a centrally administered economy.

Eucken's interpretation of Smith is all the more astonishing, reminding the fact, that Eucken's father, the world-famous philosopher and Nobel prize laureate, Rudolf Eucken, honours Smith as the climax or summit of British enlightenment - still higher than Locke, Hume, Hutcheson, Shaftesbury and all the other great thinkers of British philosophy in the $17^{\text {th }}$ and $18^{\text {th }}$ century (R. Eucken 1950: pp. 347).

It is thus the aim of this paper to show, that Walter Eucken's accusations are mainly wrong and to proof, instead, that there exist far reaching complementarities between the accounts of Smith, (Kant) and Eucken. By pursuing a less one-sided, prejudiced and stereotype approach we try to narrow the gap between so called Paleoliberalism and German Neoliberalism. ${ }^{7}$ Following the (partially unproved) theses of Ulrich (1997/2008:370), Recktenwald (1974/2005: pp. LXII/LXXV; 1985:383-384/395-396) and Ballestrem $(2001: 152)^{8}$, all claiming that Smith is among the forerunners and predecessors of Ordoliberalism and Social Market Economy, we try to provide the reader with an insight into the socio-political philosophy of Smith and Eucken, pointing at similarities and differences alike. In order to proof such theses we base our examination on a systematic primary source text analysis comparing the books and essays written by Eucken and Smith.

The paper tackles these questions in three steps: The second chapter reviews Smith's complex and interdependent system of (natural) liberty, which is similar to that of Eucken (and Kant) in linking elements of negative and positive freedom. ${ }^{9}$ The third section examines Smith's and Eucken's philosophy of the state. The paper ends with a summary of our main findings.

einander die Gesellschaft fördern“ (Eucken 1952/2004:360; cp. Eucken 1938: pp. 40; 1947: pp. 133; 2001:11-12; Dietze/Eucken/Lampe 1943:105).

7 By narrowing the gap between Paleo- and (German) Neoliberalism we are still aware of the existing divergences between Classical and Ordo-Liberalism (cp. Foucault 2006: pp. 170). It is not the aim of the paper to deny or obliterate the differences. Nevertheless, it seems appropriate - especially when dealing with Smith and Eucken - to stress the continuum and gradual transition (at least) between these two philosopher-economists.

A by-product of our differentiated approach is to provide the Anglo-Saxon scientific community with information about Ordoliberalism and the normative foundations of German Social Market Economy. The access to the work of Eucken and other main representatives of Ordoliberalism seems to be much easier via the well-known writings of Adam Smith.

8 Cp. Hutchison 1981/1992:162-163 and Zweynert 2007:7-8.

9 Cp. Berlin 1995/2006. 


\section{Smith's and Eucken's "Program of Liberty"}

\section{Eucken and the Freiburg School of Economics on Liberty}

The ordoliberal Freiburg School of Economics, often referred to as German Neoliberalism, was an interdisciplinary research community at the University of Freiburg in the 1930ies-1940ies. The main representatives of that school, including Walter Eucken, Franz Böhm and Hans Großmann-Doerth, to name just a few, were convinced, that the market economy mechanism can neither develop spontaneously nor survive unaided (i.e. Freiburg Imperative). Hence, the institutionalization of constituent and regulative principles is necessary to establish and maintain a new permanent socio-economic order - 'Ordo' simply means order - which is capable of solving the New Social Question (i.e. dependencies and exploitation of socioeconomic powers as a threat to individual liberty (Eucken 1948b)). The main characteristics of German Ordoliberalism as among the central pillars of Social Market economy are the following ones: differentiation between Ordnungs- and Prozesspolitik (rules of order vs. rules of the game), 'Interdependency of Orders', notion of 'Leistungs- ' instead of 'Behinderungswettbewerb' (competition on the merits and in terms of better services to consumers (consumer sovereignty)), market conformity of economic policy measures (Marktkonformität (Röpke 1942/1948: pp. 258)) rather than arbitrary, isolated and case-by-case interventions, and the liberal ideals: freedom of privileges, non-discrimination and equality before the law.

According to Eucken (1948a: pp. 73; 1949:27), individual liberty consists of the Kantian notion of autonomy, self-legislation and self-determination highlighting the importance of the Kantian philosophy in general and the Categorical Imperative in particular. Liberty is constitutive for humanity (Eucken 1948a:73; 1952/2004:176/369-370) and it is strongly related to human dignity: Each person is an end in itself and no instrumental mean to an end (Böhm 1950:XXXV; Eucken 1948a: pp. 75). Furthermore, freedom is necessary in order to overcome tutelage, dependency and immaturity (Eucken 1948a:74). Eucken abhors the stereotyping process (Vermassung), the mental uniformity, nihilistic soullessness, and the mental vacuity and void resulting from the at that time societal crisis (Gesellschaftskrisis) (Eucken 1926; 1932).

However, the exertion of liberty is not unlimited in an anarchical sense. The limits of freedom are reached when the exertion of liberty negatively affects the sphere of personal privacy. In other words: the exercise of one's freedom is limited by the freedom of others (cp. Kant's definition of liberty in Metaphysics of Morals (Kant 1977a:337338)). Yet, freedom has to be protected by the law-giving bodies of the state, pointing at the interrelatedness of freedom and the rule of law (Eucken 1949:27; 1952/2004:48/176). The jurisdiction - together with ordoliberal Ordnungs- and Wettbewerbspolitik and a clear-cut definition of the state's tasks - is responsible for averting the threefold dangers threatening liberty: private powers of producers, semi-public and corporatist powers of societal collectives and the powers of the state (Eucken 1952/2004:177). Eucken clearly criticizes the totalitarian interventionist state of the industrialised age and its unification of economic and political powers (Eucken 1948a:75). It is the aim of all ordoliberal representatives to implement a constitutional design with adequate restrictions and sanctions that maximizes individual liberty and 
the freedom of external (legal) compulsion and disposal, while at the same time protecting privacy and minimizing the abuse of socioeconomic power.

\section{Smith's System of Natural Liberty}

An almost identical definition of liberty can be found in Smith's oeuvre. He notes: "[e]very man, as long as he does not violate the laws of justice, is left perfectly free to pursue his own interest his own way ..." (WN 687). “... the right one has to the free use of his person and in a word to do what he has a mind when it does not prove detrimentall to any other person" (Lectures on Jurisprudence (LJ):(A) 8). "But those exertions of the natural liberty of a few individuals, which might endanger the security of the whole society, are, and ought to be, restrained by the laws of all governments ..." (WN 324). Smith's system of natural liberty, as the quotations suggest, thus, seems to be mainly a system of negative freedom, a comprehension of liberty as a defence of natural rights (Abwehr- instead of Leistungsrechte ${ }^{10}$ ): Protected and secured by the state, freedom, consists in providing a maximum leeway for the free development of the individual and at the same time, in providing the safeguard against the arbitrariness and disposal of others $^{11}$ (Kant 1977a: pp. 336; Eucken 1948a: pp. 73). Each individual should be left free to pursue his or her own self-interests (i.e. maximum of (legally confirmed) individual freedom), but - and that is crucial - within the limits of justice and as long as other persons' rights are not violated. As stated earlier, the limits of freedom are arrived at when the freedom of others is affected in the way that the practice of individual's rights is constrained. To put it differently: a law-determined freedom demands a civil constitution and a law-governed state which guarantees human rights ${ }^{12}$ : Everybody's domain of outer freedom is equally determined by a law of freedom.

However, Smith's concept of liberty (under the rule of law) is by far more complex und multifaceted, and it seems to be at odds to reduce it to a merely negative comprehension of freedom: ${ }^{13}$ It is strongly related to the political and legal institutions as the guarantor of freedom and human rights, it is connected with his concepts of property ${ }^{14}$,

10 Cp. Fleischacker 1996; 1999; 2004/2005.

11 Smith, as well as Kant and Eucken, assume a double demarcation of the private sphere: the discretionary power of disposition respectively the right of free disposal has to be safeguarded against other individuals and state authorities alike (e.g. Eucken 1952/2004:48/176).

12 Freedom as the foundation of human rights has to be institutionalised. Therefore, Smith, Kant, and Eucken speak of an individualrechtliche and ordnungspolitische safeguarding of liberty (cp. Nawroth 1961/1962: pp. 76/118 pointing at the similarities between Smith's, Kant's and Eucken's philosophy of liberty).

13 It should also be noted, that Smith's concept of liberty is not atomistic and individualistic in the kind that it ignores the well-being of a society: Liberty is highly related with (non-materialistic) opulence of a state and social cohesion (cp. Feilbogen 1892:152). Furthermore, free self-love (LJ(A) 348; LJ(B) 493/538; $E D: 571-572$ ) must be checked to the degree judged appropriate by the impartial spectator and the system of natural justice. Via an adequate institutional design the compatibility between selfinterest and public interest can be achieved - according to Smith's (and Eucken's (1952/2004: pp. 355)) optimistic point of view.

14 WN 138: "The property which every man has in his own labour, as it is the original foundation of all other property, so it is the most sacred and inviolable. [...] and to hinder him from employing this strength and dexterity in what manner he thinks proper without injury to his neighbour, is a plain violation of this most sacred property." For Smith, as well as Kant (1977a: pp. 350) and Eucken (cp. his 
justice, and normative egalitarianism ${ }^{15}$. Lastly, it is related to the Kantian notion of autonomy and independency, the process of enlightenment and emancipation, and (moral and intellectual) education. Smith's notion of liberty is dualistic in the sense that it combines negative as well as positive freedom - although the main focus is on negative freedom! ${ }^{16}$ The parallels to Kant's Metaphysics of Morals (as well as Eucken) are obvious: Both are representatives of a liberal republicanism, both are central figures of the enlightenment, and for both liberty and autonomy are central components of their arguments. Furthermore, both thinkers (and in line with Eucken's theory) are highlighting the field of tension between liberty, order and power: the free will of the individuals has to be balanced with obedience respectively the coercive and enforcement powers of the state. Otherwise human rights could not be guaranteed and the enabling of freedom would hardly be possible.

One of the key aims of Smith - as well as Kant and Eucken - is self-governance, self-command and personal independence in individuals' lives, opinions and minds (together with liberty and security of individuals). Three preconditions of liberty as autonomy are essential: the already mentioned constitutional state, a market-based economy guaranteeing a minimum standard of living, and (moral and intellectual) education: Liberty requires material as well as mental conditions - the absence of coercion and arbitrariness alone are not sufficient. ${ }^{17}$ Smith's public education system can be described as a compulsory universal schooling system aiming at the independence and maturity of individuals, and the development of the faculties of reason and speech. The state offers the institutional infrastructure (WN 785-786) and guarantees equal access to education independent of social ranks. One fundamental underlying assumption is again Smith's

constituting principles in Eucken: 1952/2004: pp. 254), property rights are grounded in the idea of liberty. Moreover, they are an essential precondition for safeguarding and protecting the individual sphere of liberty rights and for fostering personal independency. Thus, they belong to the fundaments of every civil society. Noteworthy is the fact, that Kant, Smith, and ordoliberal thinkers like Eucken assume a reciprocal interdependency of freedom and property rights (cp. Nawroth 1961/1962:404405).

15 I.e. moral (equality of worth) and formal-judicial equality (everybody is by birth equally subject to the law) together with the principle of equal opportunities and equal socio-economic starting conditions.

16 A similar combination of negative (i.e. freedom from state interference and absence of coercion; freedom of action) and positive (or Kantian) liberty elements (i.e. scope for development and selffulfilment; (rational) self-determination, self-mastery and autonomy of individuals (cp. Berlin 1995/2006: pp. 201)) can be found in Eucken's work as well: contrary to a negative or formal comprehension of liberty, positive or real liberty requires material preconditions. Therefore, Eucken underlines the eminent importance of the efficiency and functionality of an economic order. Moreover, a Wettbewerbsordnung incorporating several institutional control mechanisms (e.g. meritocratic competition; monopolies and mergers commission) is essential (Eucken 1952/2004: pp. 291; 2001) in order to approximate the ideal of the absence of power (i.e. Machtfreiheit) and to realise positive freedom rights.

17 Cp. Rothschild 2001/2002:9-10: “The two most important conditions of commercial prosperity, for Smith and for Condorcet, are the improvement of political and legal institutions and the independence of individual dispositions. "Order and good government, and along with them the liberty and security of individuals", the circumstance which is for Smith at the heart of the progress of opulence, has the effect of making possible the enfranchisement of opinions and sentiments. Individuals are free of "servile dependency"; they exert their industry "to better their conditions"; they are no longer "continually afraid of the violence of their superiors"; they have sense of their own security. [...] Independence of mind is in turn a consequence, as well as a condition, of commercial prosperity." 
normative egalitarianism: all individuals have equal natural, cognitive dispositions (i.e. natural equality (WN pp. $\left.28^{18}\right)$ ). Hence, via the inclusion of all societal classes, everyone has equal meritocratic chances to climb the social ladder. Additionally, Smith's educational system features performance-related teaching payments: It encloses competitive and rivalry elements in order to animate ambition, industry and excellence (i.e. incentives for better performance include efficiency control variables respectively teaching evaluations (WN pp. 759)). Beside the already mentioned task of overcoming tutelage and immaturity, the educational system is also capable of neutralizing the negative consequences and inconveniences of the division of labour and the commercial spirit like monotony and alienation (LJ(B) 539-540; WN pp. 782). The "dehumanization of the workers" (Griswold 1999:292) has to be stopped via education. It is the primary end of education to "... humanize the mind, to soften the temper, and to dispose it for performing all the social and moral duties both of publick and private life" (WN 774). Moreover, education can prevent moral corruption and degeneracy (WN 781), it can enhance social mobility, and - together with individual deliberation processes, public debates, criticism, and the public use of reason (i.e. freedom of speech) - it can contribute to liberate the minds of individuals from fear, terror, prejudices, unexamined and unreasonable dogmas. Thus, it helps to triumph over the poison of superstition, enthusiasm, dogmatism and fanaticism and frees morality from religion. ${ }^{19}$ Rothschild (2001/2002:71) remarks: "Freedom consisted, for Smith, in not being interfered with by others: in any of the sides of one's life, and by any outside forces (churches, parish overseers, corporations, customs inspectors, national governments, masters, proprietors). Interference, or oppression, is itself an extraordinarily extensive notion; Smith at times talks of inequality as a form of oppression, and of low wages as a form of inequity."

Free commerce - as a further precondition of liberty as autonomy - is advocated by Smith because a market-based economy fits best into the aim of reducing poverty and maximizing (material) wealth for the worst-off in a society (Early Draft (ED) 564). ${ }^{20}$

18 Cp. McCloskey 2006:121.

19 Cp. Griswold 1999:11: "Unexamined beliefs are prejudices, traditions are dogmas until reviewed by reason, and public life should be the arena of vigorous and open debate. This attitude of criticism manifests a deep ethical commitment to independence, self-sufficiency, and courage, and to freedom from the shackles of custom, nature, and fortune. The point is elegantly articulated in Kant. True "maturity" or autarchy is autonomy; it is as self-directed, self-legislating beings that we are fully human or free. Premodern thought is precritical, unfree, and in a sense immature. The path to enlightenment requires the courage of thorough self-examination ..."; see Rothschild 2001/2002:14: "The great promise of commercial and liberal society - of the liberal plan of equality, liberty and justice [...] - is that the minds of individuals will be less frightened, and their lives less frightening. Commerce will flourish only in a state with a regular administration of justice, or in which there is a "certain degree of confidence in the justice of government."'

$20 \mathrm{Cp}$. Smith's moral assessment and approval of capitalism: According to Smith, a commercial economy does not only lead to a price reduction and an increase in the standard of living of the worst-off. Commerce also has a significantly positive influence on human behaviour and its virtuousness (i.e. moralizing and ordering effect of free trade). A commercial spirit encourages virtues of probity, selfrespect, self-command, independency, autonomy and liberty. Moreover, it fosters diligence, industry, hard work (LJ(A):364; LJ(B):511-512/522), and it introduces probity, parsimony, punctuality and additionally, honesty and trust as social capital (LJ(B):528/pp. 538). Cp. Griswold 1999: pp. 180; McCloskey 2006:306 for information about Smith as a virtue ethicist. 
Free commerce supplies the wants of the artisan and the peasant alike (ED 566). It ceases subsistence to be precarious, prevents famines and scarcities, and it provides a minimum standard of living, ensures more equal subsistence and supplies the public with "mutual communication of knowledge and of all sorts of improvements" (WN 627 ) - that is Smith's (and Eucken's) belief. The reduction of poverty is essential for the socio-economic independence of individuals. Freedom of commerce is therefore a mean for the emancipation from personal, political and physical oppression. A commercial economic society decreases suppression and dependency among workers and labourers - one crucial requirement is of course the rule of law respectively good governance. ${ }^{21}$ In addition, the participation in market exchange processes and the spread of commerce encourages and fosters maturity, independence, autonomy, liberty, and virtues like probity, self-reliance, self-government, and self-command. ${ }^{22}$

In this context, Smith excoriates monopolies and exclusive privileges of guilds, bounties, crafts and corporations and their despotism and abuse of power (LJ(B) pp. 527; WN pp. 135/470/pp. 591/pp. 628/ pp. $733^{23}$ ) - one of the leitmotifs of Smith (and Eucken) pervading the whole oeuvre: According to Smith and Ordoliberalism, all kinds of privileges "as real encroachments upon natural liberty" (WN 470) obstruct and restrain competition (WN 733-734). This leads to higher prices and profits, lower quality of commodities, and lesser opulence and wealth; yet, they damage public interests. Moreover, they repress, restrict, and violate natural liberty (as autonomy) and justice. The exclusion of individuals as well as the fact that laws are solely enacted for the benefits of the rich, powerful and informed insiders is unjust (workers, on the contrary, belong to the outsider community). Besides this more economic, ordoliberal argumentation, privileges are critical from an ethical point of view as well, because they violate the non-discrimination and equality of treatment principle.

Remarkable is the interrelatedness of political, ethical and economic spheres Eucken (1952/2004:183) speaks of the "Interdependency of Orders": Smith and

21 Cp. Rothschild 2001/2002:27; Winch 1978:97.

22 LJ(B): 487: "Nothing tends so much to corrupt mankind as dependencey, while independency still encreases the honesty of the people. The establishment of commerce and manufactures, which brings about this independencey, is the best police for preventing crimes. The common people have better wages in this way than in any other, and in consequence of this a general probity of manners takes place thro' the whole country. No body will be so mad as to expose himself upon the highway, when he can make better bread in an honest and industrious manner"; LJ(A):332: "In generall we may observe that the disorders in any country are more or less according to the number of retainers and dependents in it"; LJ(A): 333: "Their idle and luxurious life in ease and plenty when with their masters renders them altogether depraved both in mind and body, so that they neither are willing nor able to support themselves by work, and have no way to live by but by crimes and vices. [...]; and we may also affirm that it is not so much the regulations of the police which preserves the security of a nation as the custom of having in it as few servants and dependents as possible. Nothing tends so much to corrupt and enervate and debase the mind as dependency, and nothing gives such noble and generous notions of probity as freedom and independency. Commerce is one great preventive of this custom."

23 According to Smith, monopolies and their "dazzling splendour" (WN 628) lead to extraordinary waste, fraud and abuse. They derange the natural distribution of stock and encourage adventurers (WN 631-632/672-673). In addition, they inhere an oppressive and monopolizing spirit of regulated companies (WN 737-738). Nevertheless, Smith legitimates temporary monopolies (i.e. infant industries argument), but not perpetual monopolies (754-755) - otherwise higher prices and exclusion from different markets (i.e. barriers to entry) and branches would result. 
Eucken are not only concerned with economic freedom (i.e. economic liberalism); ethical and political freedom (i.e. ethical-political liberalism) are at least as much as essential as economic freedom. In addition, Smith pursues a two-stage argumentation similar to that of Eucken: efficiency and allocation arguments are mixed up with ethical arguments concerning liberty, justice respectively oppression and injustice. Free trade does not only promote economic productivity but also justice and (positive) liberty in the sense of (Kantian) autonomy. The ordoliberal aim is quite similar: the promotion of a functioning and efficient economic order and - at the same time - a humane and just order of society (Eucken 1952/2004:166).

Due to the fact that liberty has to be seen in the field of tension between the exertions of freedom on the one hand, and power, law, and order on the other hand (i.e. idea of liberty under the law), we have to take a closer look at Smith's and Eucken's concept of the state.

\section{Smith's and Eucken's Concept of the State}

\section{Smith's Concept of the State}

At the heart of Smith's concept of the state lies the primacy of law respectively the rule of law. Each person has fundamental, innate and inalienable human rights like the right to life and physical integrity, the right to freedom (of action and expression), and property rights ${ }^{24}$. The government and all the other legal institutions are obliged to guarantee, protect and respect these natural rights - or as Smith would put it: the state has to implement a legal order which secures these perfect rights. Socio-political interventions into the individual sphere have to be legitimated and this means that they have to be consensual and generally agreeable; they have to be in accordance with natural justice and the impartial spectator.

In order to establish an institutional setting of legal protection, Smith favours a republican governmental system (LJ(B) 404; cp. Kant's Perpetual Peace and The Contest of Faculties): a republic is either an aristocracy or a democracy. While Smith is rather sceptical of a democracy and a monarchy, as the third type of government, he sympathizes slightly with an aristocracy. However, the form of government is not as much as important as the modality of governance itself or the way politics is operated. The main aim is the implementation of a liberal constitutional state which is capable of protecting

24 LJ(A) 10-17/104; LJ(B) 404-405/475; Kant 1977a: pp. 350; Smith defines property - "the grand fund of all dispute" (LJ(A) 208) - as follows: "Property is to be considered as an exclusive right by which we can hinder any other person from using in any shape what we possess in this manner" (LJ(A) 10). He continues to say: "The more improved any society is and the greater length the severall means of supporting the inhabitants are carried, the greater will be the number of their laws and regulations necessary to maintain justice, and prevent infringements of the right of property" (LJ(A) 16). He finally admits: "Law and government, too, seem to propose no other object but this; they secure the individual who has enlarged his property, that he may peaceably enjoy the fruits of it. By law and government all the different arts flourish, and that [useful (LJ(A) 338)] inequality of fortune to which they give occasion is sufficiently preserved. By law and government domestic peace is enjoyed and security from the forreign invader." (LJ(B) 489). In TMS (64), Smith adds the modern notion of commitment, social responsibility and the ethical obligation of owners and proprietors. 
the perfect rights: justice, liberty, and equality (equality before the law and equality of opportunities). Hence, Smith's ideal constitution, a law-governed state, consists of several power-concentration and -abuse restricting and limiting mechanisms like the separation of powers ${ }^{25}$, the regularity of elections, the impeachment of ministers of maladministration and the educational system promoting the public use of reason and freedom of expression (LJ(A) pp. 271/315; LJ(B) 421-422/pp. 522; Kant 1977a: pp. 431; 1977b: pp. 206-207). Ministers and kings have to serve their country, they are the servants of the people (TMS 53), and they cannot overrule the ordinary people or act contrary to justice and (natural) law (LJ (A) 272-273/315; TMS 64 (i.e. Smith's social criticism is a strong leitmotif of his oeuvre)). To avoid oppression and to restrain the arbitrariness of the decision making processes it is necessary to establish the aforementioned ordoliberal control mechanisms and to implement transparent and strict general rules which limit the states' competences (LJ(B) 434). In the case of breaching or disobeying the limits of powers - especially when the magistrate breaks the original contract via violating perfect rights and the dignity of the person - each individual has a right to resistance. Smith comments on the ordoliberal topic of the limits of power and the abuse of powers: "... there are certain limits to the power of the sovereign, which if he exceeds, the subject may with justice make resistance. [...] The power of the sovereign is in this case a trust reposed in him by the people; [...] but when he has abused this power in a very violent manner, [...] then undoubtedly he may be resisted as he is guilty of a breach of the trust reposed in him. - When he abuses his power and does not exert it for the benefit of the people for whose advantage it was given him, but turns it to the aggrandizing and exalting of himself, then he may be turned out of his office ..." (LJ(A) $\left.315-316^{26}\right)$. Smith declares a duty to obey when the governance is legitimate, but he also declares a right to resistance in all those cases when the rules of justice and natural jurisprudence are exceeded and when the public welfare is (negatively) affected.

In LJ, Smith distinguishes four public tasks: justice, police, revenue, and arms. The main responsibility of the state is the preservation of (commutative) justice ${ }^{27}$ and the

25 I.e. the independency of judges and the members of parliament as controlling or restraining bodies of the executive government and therefore guarantors of freedom (LJ(A) 200; LJ(B) 405). Judges are according to Smith - "the source of our liberty, our independence, and our security" (LJ(A) 313). These kinds of countervailing powers are implicitly incorporated into Eucken's Ordoliberalism as well. Moreover, Eucken establishes further control variables on the constitutional level like the principle of competitive markets, (unlimited) liability, and relative or restricted freedom to sign contracts (not all kind of contracts are allowed; especially contracts limiting the degree of competition, excluding economic agents, and promoting cartels, oligopolies, and monopolies are prohibited; cp. Eucken's (1952/2004: pp. 254) constituting and regulating principles).

26 LJ(A) 291-324; LJ(B) pp. 427; TMS pp. 231.

27 Smith's and Eucken's concept of justice focuses on corrective, retributive and commutative justice (i.e. justice of contracts and exchange or in German: Markt-, Tausch- and Vertragsgerechtigkeit). The reason for the limited scope of distributive justice is their aversion against paternalism, despotism and the welfare state incorporating arbitrary and ad-hoc Prozesspolitik and Punktualismus. Contrary, they highlight the importance of justice of rules and procedures (Regel-/Verfahrensgerechtigkeit instead of Ergebnisgerechtigkeit) containing the institutional-ethical criteria reciprocity (i.e. equivalence of performance and reward/return service), impartiality, equality of treatment and subsidiarity. Redistributive elements are contained in the taxation policy (i.e. taxation of income on a progressive scale; ability to pay principle), minimum wages/minimum standard of living (i.e. prevention of working poor and care for the worst-off in a society), and government funded programs (i.e. providing pub- 
maintenance of the legal order. Second come police, revenue, and arms. The term 'police' enclose the liability for the social order and public security, the cleanliness, hygiene and public healthcare, the cheapness and plenty of goods and services, and the wealth and prosperity of a nation. 'Revenue' and 'arms' - on the other hand - stand for the fiscal or financial policy ${ }^{28}$ respectively the national defence, military organisation, and the law of nations (LJ(A) pp. 5; LJ(B) 398/486). Mainly in the $5^{\text {th }}$ book of WN Smith puts the duties and responsibilities of the state in concrete terms: Smith's overriding aim is to legitimate the intervention of the state into the private sphere of individual liberty. In WN, he distinguishes only three - instead of four as we have seen in the LJ objects, where state interventions ${ }^{29}$ are legitimate and essential: Besides the already mentioned tasks of national defence $e^{30}$ and administration of justice (i.e. protection of the individual against injustice and oppression ${ }^{31}$ ), he discusses the educational system ${ }^{32}$, the disposal of external effects, and the supply of public goods and institutions (WN 688/pp. 723).

lic resources like public schooling and education) (e.g. Eucken's regulating principles in: Eucken 1952/2004: pp. 291).

28 Smith's revenue and taxation policy is based on four maxims (WN 814/pp. 825/pp. 867): 1. the ability to pay principle assuring tax equity, 2. the principle of non-arbitrariness and reliability of taxation, 3 . the principle of convenience, and 4. the principle of efficiency and providing economic incentives (LJ(A) 6; LJ(B) 514-515). Smith argues here for a just taxation system, which guarantees the equal treatment of each tax payer according to strict and transparent laws (i.e. equal tax treatment) and an equal contribution to the national revenues according to the individual socio-economic abilities (i.e. fair distribution of the tax burden). Moreover, he argues against oppressing tax burdens which would decrease industry and trade incentives, and therefore diminish the opulence of a state (LJ(A) 353), and he argues against an excessive taxation bureaucracy, which increases the incentives of tax evasion. The similarities to Eucken's (1952/2004:300-301) regulating taxation principles are more than obvious.

29 WN 687-688; Viner 1985; Feilbogen 1892:157.

$30 \mathrm{WN}$ pp. 689/707.

$31 \mathrm{WN}$ pp. 708; the administration of justice (including jurisprudence and inner safeness) aims at the reduction of uncertainty and discrimination in economic transactions, and the protection of property rights (WN 709-710). The regulative legislature has to be impartial and equal (i.e. neutrality and equality of treatment (WN 717)). A special interest group policy has to be ruled out as well as abuse and corruption of the administration of justice (WN pp. 716). Smith, therefore, demands - among other things - competitive and performance-related wages (WN 719) and an institutionalised separation of powers (WN 722-723): "When the judicial is united to the executive power, it is scarce possible that justice should not frequently be sacrificed to [...] politics. The persons entrusted with the great interests of the state may, even without any corrupt views, sometimes imagine it necessary to sacrifice to those interests the rights of a private man. But upon the impartial administration of justice depends the liberty of every individual, the sense which he has of his own security. [...] The judge should not be liable to be removed from his office according to the caprice of that power. The regular payment of his salary should not depend upon the good-will, or even upon the good oeconomy of that power."

32 Public education can contribute to the enlightenment (i.e. public use of reason), to the character or personality building of the ordinary people (i.e. virtuousness), to consumer sovereignty (WN 146/660; Eucken 1952/2004:49/163), and for counterbalancing the negative effects of labour division and the unequal distribution of property and wealth. 


\section{Exclusive Privileges, Special Interests and the Necessity of Ordnungs- politik}

A further implicit task of government is the fight against monopolies, exclusive privileges ${ }^{33}$, special interest and lobbying groups preventing the realisation of Smith's normative egalitarianism: Smith's ideal (WN 471) of a well-governed economic system is one where a free market mechanism prevails with high wages, low prices and profits, but with a high degree of competition on the merits (Eucken and other representatives of Ordoliberalism speak of Leistungs- instead of Behinderungswettbewerb which has to be established (Eucken 1952/2004:247/267/297). In order to succeed, the institutional setting should be designed in a way to avoid the influence of partial interest groups on the political decision making process. The main task of government is its commitment to common welfare of the whole body of society and not the well-being of sociopolitical elites, while the rest of society is excluded (WN 471-472). 'Implicit' means that Smith rarely points explicitly at that ordoliberal governmental duty - however, his argumentation in LJ, WN (pp. 591), and in his Correspondences suggests this completion of his argumentation. This completion is at first realised by Eucken and other Ordoliberals, who add further control mechanisms to the already existing control variables in Smith's system of natural justice and liberty.

The great drawback of market-dominating, "engrossing" and "forestalling" (WN pp. 532) monopolies and cartels ${ }^{34}$ - Eucken (1947:139/pp. 145; 1952/2004: pp. 265; 1999: pp. 25; 2001: pp. 13/pp. 79/85-86) speaks of "Marktmacht", "Marktbeherrschung", "Machtkonzentration" or "Vermachtung", which are the German translations for the just mentioned Smithian terminology - is the rising of commodity prices while at the same time the quality of goods and services decreases. Moreover, monopolies tend to diminish the division of labour, they tend to increase poverty and decrease the wealth of a nation, and they discourage industry and improvements in the form of technological innovations. ${ }^{35}$ In his Correspondence, Smith polemicises against monopolies and regulations of commerce because they are strongly correlated with corruption and privileges,

33 TMS pp. 231: "That they are all subordinate to that state, and established only in subserviency to its prosperity and preservation, is a truth acknoweledged by the most partial member of every one of them. It may often, however, be hard to convince him that the prosperity and preservation of the state require any diminution of the powers, privileges, and immunities of his own particular order or society." Partiality incorporates the "highest degree of arrogance": "It is to erect his own judgment into the supreme standard of right and wrong. It is to fancy himself the only wise and worthy man in the commonwealth, and that his fellow-citizens should accommodate themselves to him and not he to them. [...] and consider the state as made for themselves, not themselves for the state" (TMS 234); TMS 340-341: “... the interest of particular orders of men who tyrannize the government ..."; WN 471-472: "This monopoly has so much increased the number of some particular tribes of them, that, like an overgrown standing army, they have become formidable to the government, and upon many occasions intimidate the legislature. [...] The legislature, were it possible that its deliberation could be always directed, not by the clamorous importunity of partial interests, but by an extensive view of the general good, ought upon this very account, perhaps, to be particularly careful neither to establish any new monopolies of this kind, nor to extend further those which are already established."

$34 \mathrm{Cp}$. for more information about Smith's analysis of monopoly, employer and political power and coercion: Samuels 1973; Streissler 1973; Elliott 2000.

35 LJ(A) 84(-85); LJ(B) 472; WN pp. 78. 
and because they "poison" and "deceive the poor." 36 In a letter to Henry Dundas, dating from 1 Nov. 1779, he decries the injustice, unreasonableness and absurdity of monopolies and the like. "Monopolists very seldom make good work [...] but in what respect did they hurt the public? [...] They only poison the poor people [...]. Bad work and high price have been the effects of the monopoly [...]. Quackery, imposture, and exorbitant fees ..." Smith concludes: „That in every profession the fortune of every individual should depend as much as possible upon his merit, and as little as possible upon his privilege, is certainly for the interest of the public" (letter to William Cullen, dating from 20 Sept. 1774).

Smith's scepticism and distrust, his criticism of contemporary society - politicians (WN $617^{37}$ ), entrepreneurs, administrations and bureaucracies, feudal system and commercial society alike -, is concerned with corruption and the abuse of partially hidden semi-public, not quite private and not quite public powers. His criticism touches upon the arbitrary (i.e. arbitrariness as a threat to liberty), ad hoc and case-by-case jurisprudence and politics - depending primarily on special interest groups (Böhm 1937; 1961; Eucken 1952/2004). The government should ideally stand above partial interests; it should present the general will of all citizens, it should guard the general interests against the abuse of powers, and it should defend "common liberty against such oppressive monopolies [restricting personal self-fulfilment]" (WN 140). Instead, particular rent seeking and lobbying groups influence and exert pressure on the legislation process. Impartial administration of justice is demanded as well as the minimizing of discretionary powers. In order to secure consumer's sovereignty and personal liberty, Smith's (and the Ordoliberal's) aim has to be seen in making government as little dependent as possible on individuals and special interest groups. A clear, precise and general (rule of) law is necessary as well as institutionalized (and republican) checks and balances (i.e. most importantly separation of powers and competition minimizing all forms of economic oppression (i.e. monopolistic privileges; Eucken 1999; 2001)). Therefore, Ordoliberalism demands the dissolution and disintegration of socio-economic interest groups and the favouritism of Ordnungs- rather than Prozesspolitik (cp. Eucken's Principles of Economic Policy in Eucken 1952/2004: pp. 334): The state as an ordering and regulating power ('ordnende Potenz') is responsible for consciously and consistently designing and shaping the rules of the game (i.e. deliberate constructivism) and the implementation of a judicial-institutional framework (i.e. institutions of 'Marktverfassung'). Required is a clear-cut definition of the public tasks and the limits of public policy. Furthermore, government interventions within the limits of the ordering policy have to be in line with the market (i.e. ordoliberal criterion of 'Marktkonformität'). While Ordnungspolitik is at the heart of Ordoliberalism, Prozesspolitik is the kind of policy which has to be avoided: Prozesspolitik and its high degree of ad hoc, arbitrary and case-by-case interventionism into market transactions increases the discretionary powers of special interest groups and violates the conformity with market principle. The main ethical criteria for Smith and Eucken on the socio-political as well as on the ethi-

36 Letter to Le Duc De La Rochefoucauld (dating from 1 Nov. 1785): “... the regulations of Commerce are commonly dictated by those who are most interested to deceive and impose upon the Public."

37 Cp. Stigler 1985:224. 
cal level are impartiality, generality and universality. Smith's impartial spectator is on both levels the essential touchstone and the corrective of egoism of special interest groups. Not the pursuit of self-interest is the main problem, but particularism and partiality. ${ }^{38}$

Smith (and Eucken) advocates free trade because of its benefiting effects especially for the poor and worst-off in a society (WN 494). The benefits of trade are mutual and reciprocal - it is not a zero-sum game, instead it is a win-win-situation for all participants. Free market forces serve the public good much better (LJ(A) 307/390; LJ(B) 512). All kind of policies and institutions intervening in the individual deliberation process $^{39}$ and interrupting free trade agreements raise the market price above the natural price. They destroy the natural equilibrium (WN pp. 591) and hence, they decrease public opulence which is extremely hurtful especially for those who are at the bottom of the socio-economic pyramid. Thus, Smith - in accordance with Eucken - pleas for the abolition of duties, customs, excises, prohibitions and economic restrictions in general as well as the closing down of monopolies and privileges of all kind (LJ(A) 86). Instead, he - as well as Eucken - favours free concurrence, liberty of exchange, freedom of trade, and an uninterrupted commerce (LJ(A) 363; LJ(B) pp. 512). Smith notes: "But the policy of Europe, by not leaving things at perfect liberty, occasions other inequalities of much greater importance. It does this chiefly in the three following ways. First, by restraining the competition (i.e limited access to markets and branches) [...], and thirdly, by obstructing the free circulation of labour and stock ..." (WN 135(-136)). "Whatever keeps goods above their natural price for a permanencey, diminishes a nations opulence. Such are: $1^{\text {st }}$ All taxes upon industry [...]. $2^{\text {ndly. }}$ Monopolies also destroy public opulence. [...] It is the concurrence of different labourers which always brings down the price. In monopolies such as the Hudson's Bay and East India companies the people engaged in them make the price what they please. $3^{\text {rdly. }}$ Exclusive priviledges of corporations [i.e. guilds, bounties, magistrates settling, regulating and fixing prices and restricting competition] have the same effect." (LJ(B) 497). ${ }^{40}$ The same holds true - but with opposite signs - for subsidies bringing the market price below the natural price and therefore diminishing public opulence as well by imposing malfunctioning incentives

38 WN 612: "To promote the little interest of one little order of men in one country, it hurts the interest of all other orders of men in that country, and of all men in all other countries"; "It is thus that the single advantage which the monopoly procures to a single order of men is in many different ways hurtful to the general interest of the country."

39 WN 531: "But the law ought always to trust people with the care of their own interest, as in their local situations they must generally be able to judge better of it than the legislator can do"; WN 456: "The stateman, who should attempt to direct private people in what manner they ought to employ their capitals, would not only load himself with a most unnecessary attention, but assume an authority which could safely be trusted, not only to no single person, but to no council or senate whatever, and which would nowhere be so dangerous as in the hands of a man who had folly and presumption enough to fancy himself fit to exercise it. To give the monopoly of the home-market to the produce of domestick industry, in any particular art or manufacture, is in some measure to direct private people in what manner they ought to employ their capitals, and must, in almost all cases, be either a useless or a hurtful regulation"; cp. Hayek 1975 (i.e. pretence of knowledge).

$40 \mathrm{LJ}(\mathrm{B}): 522:$ "One great hindrance to the progress of agriculture is the throwing great tracts of land into the hands of single persons." Smith criticizes the engrossment of lands, the right of primogeniture (LJ(B):524-525), and "The keeping land out of the market always hinders its improvement" (525). 
and socio-economic distortions and biases. Such unbalanced disequilibria lead to a loss of opulence and harm common interests (LJ(B):498; WN pp. 146).

However, Smith is naively misleading when he concludes: "Upon the whole, therefore, it is by far the best police to leave things to their natural course [i.e. perfect liberty], and allow no bounties, nor impose taxes on commodities" (LJ(B) 499; cp. LJ(A) 351; WN 116). This statement associates with the libertarian notion of laissez faire. Smith seems to neglect the ordering function of the state, and the fact that competitive markets demand institutions of governance and a 'strong state" ${ }^{41}$ focusing solely on the rules of the game (i.e. order of rules, or as Eucken puts it: Ordnungspolitik). Competition, self-regulating liberty, and market mechanisms alone are insufficient to sustain a just and peaceful society; there exists an inherent tendency towards cartelisation and refeudalisation (Eucken 1952/2004:31 ("Hang zur Monopolbildung"). ${ }^{42}$ Economic policies that institutionally frame - in the sense of defining the general terms under which

41 A strong state is not to be confused with a totalitarian or authoritarian one. It simply indicates that the state should stand above partial interests.

42 Contrary to Eucken (1952/2004: pp. 350), Smith assumes that the invisible hand leads to the (selfrealising) compatibility of self-interest and the common good, that a socio-economic harmony and balance is achievable and that the (god-given) natural order is self-fulfilling. This is all the more astonishing reminding the fact that Smith is well aware of the existing disharmonies and conflicts of interests between labourers and employers (WN pp. 83) resulting from the asymmetric, and unequal power structures respectively the higher bargaining power on the side of the entrepreneurs (i.e. acknowledgment of the actual power structures). Smith's intervention on behalf of the underprivileged aims at counterbalancing this unequal exertion of influence: While describing the living conditions of the contemporary (i.e. unschooled and untaught) poor in the inegalitarian class-structured British transitional society (WN 869-870), Smith points at the widening income gap and the socio-economic disparities between the rich and the poor. He unmasks the societal prejudices and stereotypes of the elite concerning the labouring poor, and he - as a quasi-spokesperson of a group whose voice is in the public deliberations little heard and less regarded (WN 266/645) - aims at the break-down of rigid class barriers and the promotion of social mobility via education (and thus the transformation of the commercial society into a meritocracy). However, Smith does not only aim at overcoming and solving the social question of his time (cp. Eucken 1948b), he is also highly critical of egoism and the selfish behaviour of businessmen diminishing the public welfare. Generally speaking, Smith's (ordoliberal) view of entrepreneurs is quite ambivalent: on the negative side, Smith notes the employer's tendency to anti-competitive collusions (in the form of cartels and oligopolies), to conspiracy, to an unjustified enrichment at the expense of the public. He doubts their moral integrity; instead he insinuates a double moral standard. Furthermore, he disapproves their corrupting of morals and their ability to influence the legislation and decision making processes and therefore, their capability to enforce particular interests - manufacturers and merchants are an influencing minority with high power potentials and a lot of exclusive privileges (cp. Eucken 1952/2004, 1999, 2001 ${ }^{42}$ ). Their behavior is not only morally objectionable; it is also economically inacceptable, because of its negative economic consequences (i.e. the social indifference of monopolists and the apparent unavoidable partiality discourages the rest and breaks the natural proportion and distribution). Additionally, they hurt common welfare with their extremely risky, incalculable, adventurous and socially irresponsible speculations and misconduct (i.e. incompatibility of business habits and the public good). Projectors and their short-term orientation tend to profusion and prodigality instead of parsimony and frugality, and even to illegal businesses (WN 127-128/pp. 330). On the positive side, Smith praises the employers for their economic competences, professionalism, and skills (WN 342). Entrepreneurs and their internalized acquisitiveness and profit seeking is the engine of inventions, innovations and economic booms. Therefore, the opulence of a state depends significantly on this societal class. However, because of their lacking transparency, openness and sustainability, and because of not taking the interests of the stakeholders into account, mistrust and caution is advisable (WN 144-145/158/266-267/493-494/640/648/752/758/818). 
market transactions are carried out - instead of influencing or intervening into market processes and the play itself (order of actions) as the Prozesspolitik ${ }^{43}$ would do, are requisite in order to establish Leistungswettbewerb (i.e. consumer sovereignty and competition in terms of better services to consumers). This difference between Ordnungs- and Prozesspolitik respectively between the rules of the game $\left(\right.$ Spielregeln $\left.^{44}\right)$ and the moves/transactions within the rules of the game (Spielzüge) ${ }^{45}$ is one of the essential inventions of the ordoliberal Freiburg School. Eucken (2001:77) writes: "The state should influence the design of an economic framework, but not itself direct economic processes. [...] State planning of forms - Yes! State planning and control of the economic process - No!" (translated by the authors; cp. Eucken 2001:48).

Smith, on the one hand, seems to focus more on the individual-or virtue ethical level (e.g. concept of sympathy and impartial spectator), while at the same time partially underestimating and neglecting the institutional-ethical level. His concept lacks a systematic and consciously designed Ordnungspolitik (i.e. regulatory framework and institutional setting). Eucken, on the other hand, focuses more on the macro and meso level: a strong state is necessary in order to safeguard the constitutionalised market game and in order to create a socio-economic order which equally guarantees economically efficient and humane living conditions. Nevertheless, Smith, by pointing at central elements of the later Freiburg School like the limiting of group influence, and the moderation of partiality and interestedness, paves the way for Ordoliberalism and Social Market Economy: So, classical liberalism is among the normative foundations of Ordoliberalism.

According to Recktenwald (1985: pp. 112/pp. 380), Patzen (1990) and Hauer (1991), Smith distinguishes four formal and informal sanctions of human behaviour restricting and canalizing the natural selfishness and self-love ${ }^{46}$ of human beings ${ }^{47}: 1$. empathy (i.e.

43 The reason for favouring Ordnungs- instead of Prozesspolitik is presented by Smith himself (so it is quite astonishing that Smith does not draw the consequent conclusions as Ordoliberalism does; he seems to get stuck halfway): WN 687: "The sovereign is completely discharged from a duty, in the attempting to perform which he must always be exposed to innumerable delusions, and for the proper performance of which no human wisdom or knowledge could ever be sufficient; the duty of superintending the industry of private people, and of directing it towards the employments most suitable to the interest of the society." The quotation reminds the reader of Hayek's pretence of knowledge, evolutionary and spontaneous order, and 'Competition as a Discovery Procedure' (Hayek 1968/2002; 1975). This (optimistic and in a certain way naïve) trust in the self-regulation and self-healing capacities of markets distinguishes not only Hayek and Eucken; it also separates Eucken from Smith, who seems to hold a similar position as Hayek; cp. WN 343/540/630.

44 Eucken 1938:53-54.

45 Cp. Homann/Lütge 2004/2005; Pies 2002; Suchanek 2001/2007; Vanberg 2008.

46 It should be noted, that self-love is but one of many parts of the nature of human beings. Thus, Smith is not advocating a (solely) homo oeconomicus conception. He rather presents the diverging anthropological, psychological, and motivation-related aspects and conditions of human life in a realistic and pragmatic way (the homo oeconomicus is a part of it as well as the homo moralis, self-interest as well as altruism (cp. Fleischacker 2004/2005:82)). Therefore, it is implausible to conclude that Smith makes economic materialism an absolute, that he justifies the primacy of economics, that he fosters the disciplinary decoupling of ethics and economics, and the actual abandonment of the Aristotelian trias of ethics, politics and economics, as Nutzinger/Hecker (2008: pp. 549) postulate. Rather, he is quite critical of economic totality and aims at tempering the idea of an economic man (cp. Sen 2009; 2010). 
fellow-feeling/sympathy, imagination, (self-)reflection, individual conscience), and the impartial spectator as a deontological sense of duty (TMS pp. 161), guilt and natural justice; 2. the general public, public opinion, and informal moral rules or rules of propriety; 3. formal legislation of political institutions and the positive law reflecting the moral approval and the moral sense based on natural justice (i.e. the state as the author of legal norms and as a depersonalised, higher order (of morality)); 4. socio-economic competition, concurrence and rivalry. These individual- and institutional-ethical control mechanisms provide for a socially acceptable self-control, and prevent uncontrolled egoism, greed and avarice. The formal-institutionalised as well as the meta-economic or ethical embeddedness of market powers is one of the core preconditions for the complementarities of private and public interests. Rosenberg (1960: pp. 558) adds: “... the mere absence of external restraints and the freedom to pursue self-interest do not suffice, $[\ldots]$, to establish social harmony or to protect society from "the passionate confidence of interested falsehood." What are required, above all, are institutional mechanisms, which compel man, in his "natural insolence" ..." One of the requirements is "... a careful balancing of incentive, of provision of opportunity to enlarge one's income, against the need to minimize the opportunities for [antisocial] abuse [...] to make possible the pursuit of self-interest only in a socially beneficial fashion ..." An institutional order is required to actualise the linkage between self-interest and social well-being and an identity of interests between the private and the public sphere (Eucken 1952/2004: pp. 355). Smith does not assume a spontaneous identity of interests, and he is not blind to social conflicts, so the individual interests have to be channelled via an adequate institutional setting. With the control-mechanisms in mind, we can thus conclude that Smith is in some sense a forerunner, a predecessor, and one of the fathers of New Institutional or Constitutional Economics - although he is lacking a systematic account of a consciously designed regulatory framework which the Ordoliberals call Ordnungspolitik (Eucken 1950/1996: pp. 358).

Of eminent importance is Smith's distinction between egoism and avarice on the one hand and ('enlightened', or social and jurisprudential rules subordinated) self-love or self-interest on the other hand. Eucken picks up this distinction between selfishness and the (self-interested) economic principle, as he states it - Eucken, as well as Smith (cp. Eckstein 1985:124), are highly critical of pure egoism (Eucken 1952/2004: pp. 350) -, and they draw on the compatibility of self-love and public interest, respectively between self- or group interests and the common good.

47 Self-love must be checked and tempered to the degree judged appropriate by the impartial spectator (TMS pp. 40/pp. 172/pp. 308; Griswold 1999: pp. 202). While the informal constraints refer to virtues and morality in a small, face-to-face, and polis-like community, the formal constraints refer to rules, laws, and legal order in a modern-global, anonymous, and loose-knit society. This two-stage procedure (TMS 316: "necessity of virtue and good order for the maintenance of the one") can be explained by viewing Smith - as well as Kant - as intermediaries between the modern age and modernity. $\mathrm{Cp}$. on the relationship between general rules/maxims and self-interest: TMS 172-173: “... a passion, which when it keeps within the bounds of prudence and justice, is always admired in the world, and has even sometimes a certain irregular greatness, which dazzles the imagination, when it passes the limits of both these virtues, and is not only unjust but extravagant" (173). 
Although Eucken is capturing and extending (some of) Smith's control mechanisms - especially on the third and fourth level, namely the formal legislation and competition mechanisms - he himself criticizes Smith for advocating the doctrine of laissez faire and the invisible hand (however, this seems to be a misinterpretation of Smith's theory probably due to the fact that Eucken is uncritically over-taking the illegitimate criticism of the Historical School). Nevertheless, Eucken adds a fifth level of sanctions and restrictions in order to succeed in establishing the compatibility of self-interest and public interest - from Eucken's point of view it is clear that a laissez faire policy is not sufficient in reaching this aim: Eucken calls this institutional, ordoliberal level Wirtschaftsordnungspolitik. ${ }^{48}$ A systematic and deliberate market based regulatory and ordering policy is obligatory to set up an institutional framework which canalises economic transactions: Political and legal institutions frame economic processes ${ }^{49}$ and they create allocating incentive mechanisms for the economic agents (e.g. incentives for hard work, industry, as well as, innovation/invention). A central task of good governance ${ }^{50}$ is a competition or economic policy including a monopoly commission and an antitrust authority (Eucken 2001: pp. 79/85-86). What is necessary is a sustainable and continual engagement for the market-based economic order and a monitoring by competition. The state is responsible for setting the 'Datenkranz' (Eucken 1950/1965: pp. 157; 1952/2004:377-378), the framework of political regulations and institutional arrangements, within which the economic process can take place in such a manner that it promotes similarly the individual as well as the common interest. "... the competitive order which Smith [and Eucken] advocated was an institutional arrangement which was characterized, negatively, by the absence of all special privilege, and sources of market influence and, positively, by the all-pervasive and uninhibited pressures of the market place. [...] when it was surrounded by the appropriate institutions, it tied the dynamic and powerful motive force of self-interest to the general welfare" (Rosenberg 1960:560). It is the institutional design which directs private interests in better or worse ways $^{51}$ - therefore, it is the (formal and informal) setting which is to blame and not the (unconstrained) pursuit of interests.

In complete accordance with Smith, Eucken marks the limits of the state's competences: framing, regulating and 'ordering policy', yes, but no 'process policy' (i.e. caseby-case and ad hoc interventionism (Eucken 1999:3; 2001:37-38)). A 'strong state' is required in order to safeguard the market game on a constitutional level and to counter special interest groups. “... the state sets up and guarantees economic order, but it does not control [and intervene into] economic [transaction] processes. By guaranteeing economic order, the state enables free and fair competition" (Goldschmidt/Wohlgemuth 2008:268). Economic activities and competitive markets are domains implemented and maintained by the state. However, competition is not an end in itself, rather it is a mean (Lenel/Meyer 1948:XI), a mean to reach the overall aim of a functioning (i.e. efficient

48 Cp. Wünsche 1991.

49 Cp. Oncken 1877:205.

50 Smith's Correspondence: Letter to Lord Carlisle dating from 8 Nov. 1779.

51 "Smith provides us with a number of cases in which an individual's unconstrained pursuit of his or her interest will not benefit the society" (Fleischacker 2004/2005:139). 
and productive) and humane (i.e. just and liberal) socio-economic order (Eucken 1952/2004: pp. 365/pp. 369).

Coming back, once again, to Smith's concept of the state, it should be made clear enough, that it is not a laissez faire or a night watchman state one (Oncken 1877: pp. 209; Bonar 1922/2000:175) - although some comments by Smith seem to indicate that conclusion. Especially the third public task presented in $\mathrm{WN}$ - namely the implementation and maintenance of public goods, services and institutions - refutes the notion of a libertarian minimal state doctrine (Nozick 2006). A market based economy is impossible without a proper, functioning state. Friedman (1985: pp. $214^{52}$ ) is right when he points at the great variety, coverage and extension of Smith's state conception. The advantage of such an open conception is its flexibility, adaptability and transmissibility to modern times. Additionally, Smith recognizes the potential of social conflicts, disharmonies, and conflicts of interests - a blind and naïve harmoniousness or a utopianism cannot be found in Smith's oeuvre. However, Smith does not draw the consequent conclusions out of his realistic and pragmatic picture of society. These conclusions are drawn, in the first place, by Ordoliberalism: the state has to set and maintain the preconditions for a prospering market based economy (i.e. Ordnungs- instead of Prozesspolitik) at minimal restrictions of individual liberty. But, the ethical-normative fundamentals of a market based economy, which are an integral part of Ordoliberalism, are founded by Smith. Ordoliberalism, therefore, rests, among other things, upon the classical liberalism of Smith.

\section{Concluding Remarks}

Astonishing are Smith's concepts of liberty and justice because they reveal the transitional character of his moral philosophy and theory of economics, combining both negative and positive elements of liberty as well as commutative and distributive justice elements. The same holds true for his notion of the state and the ascribed public tasks and responsibilities: here, Smith integrates individual- and institutional-ethical elements. ${ }^{53}$ Smith's political philosophy based on the Aristotelian trias of economics, ethics, and politics is therefore multilayered and complex. Eucken, on the other side, (unknowingly?) picks up this dualistic concept and supplements the control mechanisms implemented by Smith with his concept of Ordnungspolitik. Remarkable are the analogies $^{54}$ between Smith, (Kant ${ }^{55}$ and) Eucken: i.e. the sharp rejection of any monopolistic

52 Cp. Viner 1985:107-108.

53 Cp. Griswold 1999:229: "Smith's effort to combine a virtue ethics inspired by the ancients with a modern jurisprudential framework of commutative justice and rights ..."

54 The analogies are all the more remarkable taking Eucken's constituent and regulative principles (Eucken 1952/2004: pp. 254/pp. 291) into account: The following principles by Eucken can also be found in Smith's work: perfect competition, open markets, private property rights (i.e. private ownership of the means of production), freedom to enter into contracts (i.e. relative freedom of contract), monopoly controls (i.e. anti-monopoly policy), and social equalization (i.e. income policy and correction of income distribution). 
structure and of any cartel dominated economy; a clear preference for market and price mechanisms, competition (as an "instrument of disempowerment” (Böhm 1961:22)) and liberty; disapproval of re-feudalisation (Vermachtung), exclusive privileges, rent seeking and special interest groups; favouritism of Ordnungs- instead of Prozesspolitik as well as a privilege-free Wettbewerbsordnung (although Smith's Wettbewerbsordnungspolitik-level is not as systematic and consciously designed as Eucken's, pointing at the divergences between classical liberalism and Ordoliberalism ${ }^{56}$ ). Further parallels exist concerning the concept of liberty and justice: Both, Eucken and Smith, are propagating mainly commutative (and procedural) justice and negative freedom (i.e. freedom from state interference and absence of coercion), yet, they are incorporating distributive justice and positive (or Kantian) liberty elements as well (i.e. scope for development and self-fulfilment; (rational) self-determination, self-mastery and autonomy of individuals). Eucken is also picking up some of the control variables established by Smith, however, he goes beyond Smith, and implements further checks and balances especially on the constitutional level - in order to fulfil the ordoliberal aim of a functioning and humane socio-economic order. Goldschmidt/Wohlgemuth (2008:268) add: “... only by shaping a legal-institutional framework for a well-functioning market order it would be possible to fulfil the $\left[18^{\text {th }}\right.$ and $] 19^{\text {th }}$ century liberal's project." Although there are some differences between Eucken and Smith (e.g. Smith's lack of a systematic, institutional socio-economic policy framing economic processes, and Eucken's lack of an (meritocratic) education policy ${ }^{57}$ ), far reaching complementarities between the two thinkers exist and the question remains open: why does Eucken underestimate and disesteem Smith's work?

\section{References}

Ballestrem, K. G. (2001): Adam Smith; München.

Berlin, I. (1995/2006): Freiheit. Vier Versuche; Frankfurt.

Böhm, F. (1937): Ordnung der Wirtschaft als geschichtliche Aufgabe und rechtsschöpferische Leistung; Stuttgart.

Böhm, F. (1950): Die Idee des ORDO im Denken Walter Euckens; ORDO 3; pp. XV-LXIV.

Böhm, F. (1961): Demokratie und ökonomische Macht; in: Institut für ausländisches und internationales Wirtschaftsrecht (ed.): Kartelle und Monopole im modernen Recht; Karlsruhe; pp. 1-24.

Böhm, F./Eucken, W./Grossmann-Doerth, H. (1936): Unsere Aufgabe; in: Goldschmidt/ Wohlgemuth (ed.) (2008): Grundtexte zur Freiburger Tradition der Ordnungsökonomik; Tübingen; pp. 27-37.

Bonar, J. (1922/2000): Philosophy and Political Economy in some of their Historical Relations; Early Histories of Economic Thought 1824-1914; London.

55 Kant seems to function as an intermediary agent between Eucken and Smith, a missing link between Paleo- and Neoliberalism: While Eucken was highly affected by the work of Kant himself and the Kant-interpretation of his father (Rudolf Eucken 1950: pp. 347/pp. 370), Kant was in favour of Smith (cp. Eckstein 2004:XXXIII, Krause 1997:4/13); see also Wörsdörfer 2010.

56 I.e. divergent relative importance and status of Ordnungspolitik.

57 Smith's ideal of education in WN could assist and complement Eucken's Wettbewerbsordnung emphasizing the ordering function of science. Furthermore, it refers to the analogies between Eucken, Kant and Smith in accentuating key terms of the enlightenment: emancipation and maturity. 
Broyer, S. (2006): Die Hinterlassenschaft der historischen Schule in Walter Euckens Ordnungstheorie und dem deutschen Ordoliberalismus; PhD-Thesis; Frankfurt.

Dietze, C./Eucken, W./Lampe A. (1943): Wirtschafts- und Sozialordnung; in: Goldschmidt/ Wohlgemuth (ed.) (2008): Grundtexte zur Freiburger Tradition der Ordnungsökonomik; Tübingen; pp. 99-115.

Eckstein, W. (1985): Zur Wissenschaftlichen Bewertung der >Theorie der ethischen Gefühle<; in: Recktenwald (ed.): Ethik, Wirtschaft und Staat; Darmstadt; pp. 123-130.

Eckstein, W. (2004): Einleitung des Herausgebers; in: Smith: Theorie der ethischen Gefühle; Hamburg; pp. XI-LXXI.

Elliot, J. E. (2000): Adam Smith's Conceptualization of Power, Markets, and Politics; Review of Social Economy, 58/4; pp. 429-454.

Eucken, R. (1950): Die Lebensanschauungen der Großen Denker; Berlin.

Eucken, W. (1926): Die geistige Krise und der Kapitalismus; Tatwelt II,1/3; pp. 13-16.

Eucken, W. (1932): Religion - Wirtschaft - Staat; Tatwelt VIII,2; pp. 82-89.

Eucken, W. (1934): Kapitaltheoretische Untersuchungen; Jena.

Eucken, W. (1938): Nationalökonomie wozu?; Leipzig.

Eucken, W. (1947): Über die zweifache wirtschaftspolitische Aufgabe der Nationalökonomie; in: Goldschmidt/ Wohlgemuth (ed.) (2008): Grundtexte zur Freiburger Tradition der Ordnungsökonomik; Tübingen; pp. 133-151.

Eucken, W. (1948a): Das ordnungspolitische Problem; ORDO 1; pp. 56-90.

Eucken, W. (1948b): Die soziale Frage; in: Ludwig-Erhard-Stiftung (ed.): Grundtexte zur Sozialen Marktwirtschaft; Stuttgart; pp. 329-339.

Eucken, W. (1949): Die Wettbewerbsordnung und ihre Verwirklichung; ORDO 2; pp. 1-99.

Eucken, W. (1950/1965): Die Grundlagen der Nationalökonomie; Berlin.

Eucken, W. (1950/1996): Deutschland vor und nach der Währungsreform; in:

Schneider/Harbrecht (ed.): Wirtschaftsordnung und Wirtschaftspolitik in Deutschland (19331993); Stuttgart; pp. 327-360.

Eucken, W. (1952/2004): Grundsätze der Wirtschaftspolitik; Tübingen.

Eucken, W. (1999): Ordnungspolitik; Münster.

Eucken, W. (2001): Wirtschaftsmacht und Wirtschaftsordnung; Münster.

Feilbogen, S. (1892): Smith und Turgot. Ein Beitrag zur Geschichte und Theorie der Nationalökonomie; Wien.

Fleischacker, S. (1996): Values behind the Market: Kant's Response to the Wealth of Nations; History of Political Thought, XVII/3; pp. 379-407.

Fleischacker, S. (1999): A Third Concept of Liberty. Judgment and Freedom in Kant and Adam Smith; Princeton.

Fleischacker, S. (2004/2005): On Adam Smith's Wealth of Nations. A Philosophical Companion; Princeton.

Foucault, M. (2006): Die Geburt der Biopolitik. Geschichte der Gouvernementalität II; Frankfurt.

Friedman, M. (1985): Adam Smiths Bedeutung für 1976; in: Recktenwald (ed.): Ethik, Wirtschaft und Staat; Darmstadt; pp. 208-221.

Goldschmidt, N./Wohlgemuth, M. (2008): Social Market Economy: origins, meanings and interpretations; Constitutional Political Economy, 19,3; pp. 261-276.

Griswold, C. L. (1999): Adam Smith and the Virtues of Enlightenment; Cambridge.

Hauer, P. (1991): Leitbilder der Gerechtigkeit in den marktwirtschaftlichen Konzeptionen von Adam Smith, John Stuart Mill und Alfred Müller-Armack; Frankfurt.

Hayek, F. A. (1968/2002): Competition as a Discovery Procedure; Quarterly Journal of Austrian Economics 5/3; pp. 9-23.

Hayek, F. A. (1975): Die Anmaßung von Wissen (Pretence of Knowledge); ORDO 26, pp. 12-21.

Hildebrand, B. (1848/1922): Die Nationalökonomie der Gegenwart und Zukunft; Jena.

Homann, K./Lütge, C. (2004/2005): Einführung in die Wirtschaftsethik; Münster.

Hutchison, T. W. (1981/1992): The Politics and Philosophy of Economics. Marxians, Keynesians and Austrians; Aldershot/Hampshire.

Kant, I. (1977a): Die Metaphysik der Sitten; Frankfurt. 
Kant, I. (1977b): Schriften zur Anthropologie, Geschichtsphilosophie, Politik und Pädagogik 1; Frankfurt.

Knies, K. (1883/1964):Politische Oekonomie vom geschichtlichen Standpuncte; Osnabrück.

Krause, J. P. (1997): Immanuel Kant und Adam Smith. Präsenz, Wirkung und Geltung der 'Theory of Moral Sentiments' in Kants Werk; Köln.

Kühn, M. (2003): Kant - Eine Biographie; München.

Lenel, H. O./Meyer, F. W. (1948): Vorwort; ORDO 1; pp. VII-XI.

List, F. (1842/1950): Das natürliche System der politischen Ökonomie; Jena.

McCloskey, D. N. (2006): The Bourgeois Virtues. Ethics for an Age of Commerce; Chicago.

Nawroth, E. E. (1961/1962): Die Sozial- und Wirtschaftsphilosophie des Neoliberalismus; Heidelberg.

Nawroth, E. E. (1965): Zur Sinnerfüllung der Marktwirtschaft; Köln.

Nozick, R. (2006): Anarchie, Staat Utopia; München.

Nutzinger, H. G./Hecker, C. (2008): Gerechtigkeit in der Ökonomie - ein unlösbarer Widerspruch?; Leviathan 4/2008; pp. 543-575.

Oncken, A. (1877): Adam Smith und Immanuel Kant. Der Einklang und das Wechselverhältniss ihrer Lehren über Sitte, Staat und Wirthschaft; Leipzig.

Patzen, M. (1990): Zur Diskussion des Adam-Smith-Problems - ein Überblick; St. Gallen, Berichte des IWE-UNISG 36.

Pies, I. (2002): Theoretische Grundlagen demokratischer Wirtschafts- und Gesellschaftspolitik Der Beitrag Walter Euckens; in: Pies/Leschke (ed.): Walter Euckens Ordnungspolitik; Tübingen; pp. 1-35.

Recktenwald, H. C. (1974/2005): Würdigung des Werkes; in: Smith: Der Wohlstand der Nationen; München; pp. XV-LXXIX.

Recktenwald, H. C. (1985): Ethik, Wirtschaft und Staat. Adam Smiths Politische Ökonomie heute; Darmstadt.

Röpke, W. (1942/1948): Die Gesellschaftskrisis der Gegenwart; Zürich.

Rosenberg, N. (1960): Some Institutional Aspects of the Wealth of Nations; Journal of Political Economy, 68/6, pp. 557-570.

Rothschild, E. (2001/2002): Economic Sentiments. Adam Smith, Condorcet and the Enlightenment; Cambridge.

Rüstow, A. (1961): Paläoliberalismus, Kommunismus und Neoliberalismus; in: Greiß/Meyer (ed.): Wirtschaft, Gesellschaft und Kultur. Festgabe für Müller-Armack; Berlin.

Samuels, W. J. (1973): Adam Smith and the Economy as a System of Power; Review of Social Economy, 31/2; pp. 123-137.

Schefold, B. (2003): Die deutsche Historische Schule als Quelle des Ordoliberalismus; in: Commun (ed.): L'ordolibéralisme allemande; Cergy-Pontoise; pp. 101-117.

Schefold, B. (2004): Bruno Hildebrand: Die historische Perspektive eines liberalen Ökonomen; in: Schefold: Beiträge zur ökonomischen Dogmengeschichte; Düsseldorf; pp. 377-399.

Schumann, O. J./Nutzinger, H. G. (2009): Ordoliberalismus und Gerechtigkeit: Zum Verhältnis von Eucken und Kant; in: Breuer/Mastronardie/Waxenberger (ed.): Markt, Mensch und Freiheit; Bern; pp. 55-78.

Sen, A. (2009): The Idea of Justice; Cambridge.

Sen, A. (2010): Adam Smith and the contemporary world; Erasmus Journal for Philosophy and Economics 3/1; pp. 50-67.

Smith, A. (1976a): An Inquiry into the Nature and Causes of the Wealth of Nations; Oxford.

Smith, A. (1976b): The Theory of Moral Sentiments; Oxford.

Smith, A. (1977): The Correspondence of Adam Smith; Oxford.

Smith, A. (1978): Lectures on Jurisprudence; Oxford.

Stigler, G. J. (1985): Der Ökonom und der Staat; in: Recktenwald (ed.): Ethik, Wirtschaft und Staat; Darmstadt; pp. 222-235.

Streissler, E. (1973). Macht und Freiheit in der Sicht des Liberalismus; in: Schneider/Watrin (ed.): Macht und ökonomisches Gesetz; Berlin; pp. 1391-1426.

Suchanek, A. (2001/2007): Die Ethik der Sozialen Marktwirtschaft; in: Ludwig-Erhard-Stiftung (ed.): Soziale Marktwirtschaft als Aufgabe; Krefeld; pp. 35-44.

Ulrich, P. (1997/2008): Integrative Wirtschaftsethik; Bern. 
Vanberg, V. (2008): Wettbewerb und Regelordnung; Tübingen.

Viner, J. (1985): Adam Smith und Laissez faire; in: Recktenwald (ed.): Ethik, Wirtschaft und Staat; Darmstadt; pp. 72-109.

Winch, D. (1978): Adam Smith's Politics. An Essay in Historiographic Revision; Cambridge.

Wörsdörfer, M. (2010): On the Economic Ethics of Walter Eucken in: Konrad Adenauer Stiftung (ed.): 60 Years of Social Market Economy. Formation, Development and Perspectives of a Peacemaking Formula; Konrad Adenauer Stiftung, Sankt Augustin/Bonn; pp. 20-41.

Wünsche, H. F. (1991): Die immanente Sozialorientierung in Adam Smiths Ordnungsdenken ein Paradigma für die Soziale Marktwirtschaft; in: Meyer-Faje/Ulrich (ed.): Der andere Adam Smith; Bern; pp. 249-274.

Zweynert, J. (2007): Die Entstehung ordnungsökonomischer Paradigmen - theoriegeschichtliche Betrachtungen, Diskussionspapier 07/8, WEI, Freiburg.

\section{Summary}

The aim of the following paper is to examine the complementarities (and divergences) between the Paleoliberal Adam Smith and the Ordoliberal Walter Eucken. Following the hypothesis that Smith is among the forerunners and predecessors of Ordoliberalism and Social Market Economy, we try to provide the reader with an insight into the socio-political philosophy of Smith and Eucken pointing at similarities and differences alike. Therefore, we base our examination on a systematic primary source text analysis comparing the books and essays written by Eucken and Smith. The paper tackles these questions in two main steps: The first part highlights Smith's and Eucken's complex and interdependent system of natural liberty. The second section reviews Smith's and Eucken's philosophy of the state. 